\title{
ULTRASTRUCTURE OF SPERMATOZOA OF SPARUS AURATA, DIPLODUS VULGARIS AND LITHOGNATHUS MORMYRUS (FAMLY:SPARIDAE) IN THE EGYPTIAN MEDITERRANEAN WATERS.
}

\section{SAMIA G.MOHARRAM}

National Institute Of Oceanograghy \& Fisheries, Kayet Bey, Alexandria, Egypt.

Key words: Spermatozoa; Sparus aurata; Diplodus vulgaris;

Lithognathus mormyrus

(Received May , 1998)

\begin{abstract}
7 he results obtained from the present study have evealed that spermatozoaof Sparus aurta, Dipldus vulgaris and Lithognathus mormyrus have spherical homgeneous electron dense nuclei. However that of $L$. mormyrus have an unusual notch shape like a bow- tie lying in the nuclear regions. In the three sparid species under investigation, the short mid-piece of the sperm contains a single ring of mitochondria encircling the basal body of the flagellum which has a typical $9+2$ structure. Therefore, the spermatozoa are of the primitive type which are characterized by the following unusual features: (a)They have two closely associated membranes between the cytoplasmic canal and the mitochondrian envelope. (b) A deep axial fossa at the base of the nucleus. (c) Only the nucleus of $L$. mormyrus has a nuclear notch. These unique features may provide a good tool for the study of the taxonomy and hybridization between species of family Sparidae. Besides, it could be possible to use the obtained results in increasing the fish production in Egypt.
\end{abstract}

\section{INTRODUCTION}

In fishes, spermatozoa are widely different in form and structure (Mattei, 1970 and Nicander, 1970). They vary from flagellate to biflagellate types having an enormous range in shape, size and structure. The number and location of organelles are also varied ( Baccetti et al ,1984; Baccetti ,1986; and Jones\& Butler ,1988).

Both light and electron microscopy of a wide spectrum of spermatozoa in bony fishes have revealed that important morphological differences can be found 
among some species (Ginsburg, 1968; and Maltei, 1970) and can be used for taxonomic purposes (Mattei and Mattei, 1974 and Baccelli et al, 1984).

Morphological description of spermatozoa using transmission and scanning microscopy has been reviewed by Mattei (1991) in 280 fish. Investigations of marine fishes remain scarce (Anguilla anguilla: Billard \& Ginsbureg, 1973; Liza aurata : Brusle ,1982; Seriola dumerili: Grau ef al ,1991)

The structure of spermatozoa is affected by both the reproductive mode and the systematic position (Gardiner, 1978 and Grier et al, 1978). Morphological differences in spermatozoa of bony fishes indicate that sub-microscopical morphology of these cells can be used as additional characters in classification as suggested by many authors (Mattei \& Mattei, 1974; Bacetti et al 1984; Lahnsteiner \& Patzner 1990; and Gwo et al 1993).

Spermatozoa in the majority of bony fishes remain unstudied As far as known, very few studies have been fulfilled describing the fine structure of spermatozoa in family Sparidae (Gwo et al, 1993).

The objective of the present work is to study the ultrastructure of spermatozoa in Sparus aurata, Diplodus vulgaris and Lithognathus mormyrus belonging to family Sparidae in the Egyptian Mediterranean waters.

\section{MATERIAL AND METHODS}

Two males of the three species used in the present study were obtained during the breeding season of Spart/s aurata and Diplodus vulgaris (DecemberFebruary 1996) and of Lithognathus mormyrus (May-July 1997). Males can be considered mature since smelt can be handly stripped from the urinogenital opening.

For transmission electron micrsocopy (TEM), small portions of the testis from each speceis were preserved in $2.5 \%$ ghtaraldehyde. Tissues were put in $0.1 \mathrm{M}$ sodium cacodylate buffer (PH 7.2) and then fixed in $1 \%$ osmium tettroxide in cacodylate buffer for 90 minutes. Tissues were dehydrated through an ascending 
series of ethanol before being embedded in resin via propylenc. Ultrathin sections were stained in 5\% aqueous uranyl acetate for 30 minutes and lead citrare for 5 minutes (Reynolds, 1963). They were then examined with a JGOL TEM 100CX microscope, in the Zoology Department, Faculty of Science, Alexandria University.

\section{RESULTS}

The mature sperm of the three sparid species are relatively simple, and elongated .They are considered to be of a primitive type each having a small rounded head, short mid-piece containing mitochondria, and a flagellum (Fig. 1: a, b $\&$ c). Spermatozoa of the three studied species under resembled each other in their head and mid-piece structure.

\section{THE HEAD}

The head of the sperm of the three species is similar in structure. In Sparus aurata ,Diplodus vulgaris and Lithognathus mormyrus, the nucleus is spherical, and covered by a nuclear envelope having the following diameters: $2 \mu \mathrm{m} ; 2.5 \mu \mathrm{m} \&$ $2.7 \mu \mathrm{m}$, respectively (Fig. la, b \& c). The nuclear fossa of the three sparid species is bell shaped in longitudinal sections. In $S$. aurata, the length of the nuclear fossa is about $1.2 \mu \mathrm{m} .(70 \%$ of the nucleus diameter), while in D.vulgaris, it is about $.2 \mu \mathrm{m} .(86 \%$ of the nucleus diameter). In L.mormyrus the length of nuclear fossa is about $1.4 \mu \mathrm{m}$. (82\% of the nuclear diameter). In the three species, the nuclear fossa contains the centeriolar complex and cytoplasm which intrudes into the posterior part of the nucleus (Fig.2a, $b \quad \& \quad c)$.

Only L.mormyrus has a peculiar nuclear notch which is bow- tie shaped and lies between the basal plate and distal centeriole (Fig.3). The chromatine of the three species is highly electron dense, compact in texture and presente within a typical double membrane. 
In the three species, the undulation nuclear envelope and plasma membrane are applied tightly to the anterior part of the nucleus, while the acrosomes are completely absent (Fig, 1 a, b \& c).

\section{CENTRIOLAR COMPLEX}

In the three sparid species, the two centrioles in each spermatozoa are oriented perpendicularly to each other and arranged at a right angle to the base of the head having a classic $9+0$ microtubular construction (Fig.2: a, b \& c). The anterior region of the nuclear fossa is occupied by the proximal centriole whereas the distal centriole is located in the posterior region of the fossa. The osmophilic ring is embedded in an electron dense surrounding the anterior end of the distal centeiole (Fig. 2: $a, b \& c$ ).

In S.aurata and Lmormyrus, the distal centriole which forms the basal body of the axoneme extends from the level of the anterior end of the cytoplasmic canal to the basal nuclear fossa. At its base, the distal centriole is traversed by a conspicuous basal plate (Fig.1: a \& b). On the other hand, the basal plate is not clearly observed in $D$. vulgaris.

\section{THE MID-PIECE}

The mid-piece of the three spermatozoa sparid species under study resembles each other. Its posterior part is invaginated to form a cytoplasmic canal.

The mid-piece consists of a single ring having spherical mitochondria which located just behind the nucleus. The diameters of which are about $1.2 \mu \mathrm{m}$. for S.aurata \& D.vulgarts and $1.4 \mu \mathrm{m}$. for L.mormyrus and possessing cristae and an electron dense matrix. Two closely opposed membranes extend between the cytoplasmic canal and the ring of mitochondria from the posterior end of the midpiece to the cytoplasmic canal which are known as cytoplasmic collar (Fig. 4: a, b \& c). 


\section{THE AXONEME}

The axoneme of the spermatozoa of the three species is covered by the plasma membrane laving the classic $9+2$ microtubular doublet construction (9 double outer tubules +2 single central tubules) (Fig.5 a, b \& c). In the cross section of the flagellum of three species appears to be circular and its width is about $0.4 \mu \mathrm{m}$. for S.aurata, $0.35 \mu \mathrm{m}$. for D.vulgaris and $0.3 \mu \mathrm{m}$. for $L$. mormyrus.

\section{DISCUSSION}

The results obtained from the present work have revealed that the spermatozoa of the three sparid species: Sparus aurata, Lithognathus mormyrus and Diplodus vulgaris are of primitive type (Mattei, 1988), however they have several unusual characteristics. The most important one is the presence of bow-tie shaped nuclear notch in the nucleus of L.mormyrus. These results are in good agreement with those of Gwo et al (1993) who observed similar structure in the sperm of Acanthopagrus schlegli belonging to family Sparidae.

The spermatozoa of the three species are devoid of an acrosome as previously observed in bony fishes (Billard, 1970; Baccetti et al, 1984; and Gwo et al, 1993). The absence of an acrosome can be attributed to the presence of micropyle in fish eggs (Ginsburg, 1968).

A reduced middle piece is observed in S.aurata; D.vulgaris and L.mormyrus which is common in teleosts with external fertilization (Nicander, 1970) In the species- performing internal fertilization- the spermatozoa are characterized by a long middle piece (Mattei, 1969).

The present results have revealed also the presence of deep axial fossa at the base of the nucleus which contains the centriolar complex and proximal portion of the flagellum. This is common in the spermatozoa of viviparous fishes e.g. Cymutogaster aggregata (Grier et al 1990). However, this structure has not been 
observed in most oviparous teleosts eg. : Anguilla japonica (Mattei \& Mattei, 1974); Liza aurara (Brusle, 1981), and Atlantic croacker (Gwo \& Amold, 1992).

Also, the mitochondria are localed adjacent to the caudal pole of the nucleus in S.aurata; D.vulgaris and L.mormyrus as in most bony fishes (Favard and Andrer, 1970; and Gwo et al, 1993). In several blenniid fishes mitochondria are located in the nuclear indentation (Lahnsteiner \& Patzner, 1990 and Silveir et al, 1990).

The present results have revealed that ultra-structure of the spermatozoa has significantly contributed to the resolution of taxonomy and phylogenetic problems (Healy, 1988; and Jamieson \& Rouse, 1998). These are in accordance with those of other authors (Mattei \& Mattei, 1974; Baccetti et al, 1984; and Lahnsteiner \& Patzner, 1990).

Although the ultrastructure of the spermatozoa has been studied in many bony fishes, yet $S$. aurata, $D$. vulgaris and $L$ mormyrus are considered to be the second members of the family Sparidae which have been dealt with after Gwo et al (1993) who studied the ultra-structure of spermatozoa of Acanthopagrus schegeli.

The results of the present study have revealed that the external and internal morphology of spermatozoa of $S$. aurata and $D$. vulgaris are markedly similar, so hybridization can be occurred. This is in a good agreement with Dujakovic and Glamuzina (1990) who succeeded in hybridization between the same two species in the Yugoslavian waters. Also hybrids were produced from other species of family Sparidae such as female Sparus sarba and male Acanthopagrus schegeli as given by Kitajima and Tsukashima (1983).

\section{REFERENCES}

Baccetti, B. (1986). Evolutionary trends in sperm structure. Comp. Biochem. Physiol., 85: 29-36. 
Baccetti , B ., Burrini , A.G. , Callaini, G.M. Mazzini. and S. Zfrunian (1984). Fish germinal cells. 1. Comparative spermatology of seven cyprinids species. Gamete Res., 10: $373-396$.

Billard, R. and A. S. Ginsburg, (1973). La spermiogénèse et le spematozoìde d' Anguilia anguilla $L$. Etude ultrastructurale. Annales Biologie Animal Biochimie Biophysique 13: 523-534.

Bruslé S . (1981). Uttrastructure of spermiogenesis in Liza aurara Risso, 1810 (Teleostei: Mugilidae). Cell Tissue Res. 217: 415-424.

Bruslè S . (1982). Contribution a la connaissance de la sexualité de poissons téléostéens marins gonochoriqus (Mugilidés) et hermaphrodites (Serranidés). Thése Univeristè de Perpignan, 360pp.

Dujakovic , J. J; and B. Glamuzina. (1990). Intergeneric hybridization in Sparidae Sparua aurata femaleX Diplodus vulgarls male. Aquaculture. 86,(4): 369 378.

Favard, P. and J. Andre. (1970). The mitochondria of spermatozoa. Comparative Spermatology. New York; Academic Press. 401-405

Gardiner, D.M.. (1978). Fine structure of the spermatozoon of the viviparous teleost, Cymatogster aggregaria J. Fish Biol. 13: 435-438.

Ginsburg , A.S . (1968) . Fertilization in Fishes and the Problem of Polyspermy. Moscow: Acad. Sci. USSR.

Grau, A., M. C. Satrasquete, and S. Crespo (1991). Spermiogenesis in Seriola dumerili Risso 1810: An ultrastructural study. Proc. Europ. Soci. For Comp. Physio.\& Biochem. Cong.

Grier, H.J., J.M. Fitzsimons, and J.R Linton (1978). Structure and ultrastucture of the testes and sperm formation in goodeid telcosts. J. Morphol. 156: 419433.

Girier, H. J . , H. J. Moody and B . C. Cowell (1990). Internal fertilization and morphology in brook silverside Labidesthes sticculus. Copia : 221-226.

Gwo, J.C ., and C.R. Amold (1992). Cryopreservation of Atlantic croaker spermatozoa . Evaluation of morphological changes. J. Exp. Zool. 264: 444-453.

Gwo, J.C., H.H. Gwo and S.,L. Cliag (1992). The spermatozoon of the Japanese eel Anguilla japonica (Teleostei : Anguilli formes, Anguillidae). J. Submi. Cross. Cytol. Pathol. 24: 571-574 
Gwo, J.C., H.H., Gwo and S.L., Chang. (1993). Ultrastructure of the spermatozoon of the telcost fish Acanthopagrus schlegeli (Perciformes: Sparidae). J. Morphol. 216: 29-33.

Healy , J.M. (1986). Sperm morphology and its systematic in the Gastropoda. Malacol. Rev. 4: 251-266.

Jamieson , B.G.M. and G. W. Rouse (1989). The spermatozoa of the Polychaeta (Annelida): An ultrastructure review. Biol. Rev . Camb. Philo. Soc. 64 93-157.

Jones, P.R, and R.D . Butler . (1988) . Spermatozoon ultrastracuture of Platichthys flesus. J. Uttrastruc. Mol. Struct. Res. 98: 71- 82.

Kitajima, C . and Y Tukashima. (1983). Morphology, growth and low temperature and low salinity tolerance of sparid hybrids. Japan. J. Ichthyol., 30: 275-283.

Lahnsteiner , F . and R A. Patzner . (1990). Spermiogenesis and stracture of mature spermatozoa in blenniid fishes. (Pisces: Bienniidae). J. Submicrosc. Cytol. Pathol. 22: 565-576.

Mattei , C . (1970). Spermiogeneses comparee des poissons. In B. Baccetti (ed). Comparative Spermatology. New York, Academic Press, 57-69.

Mattei, C. and X. Mattei . (1974). Spermiogensis and spermatozoa of the elopomorpha (teleost fish). In B.A. Afzelius (ed): The functional anatomy of the spermatozoon. New York: Pergamon Press, 211-221.

Mattei, X . (1969). Contribution àétdue de la spermiogénése et des spermatozoïdes de poissons par les méthodes de microscopie électronique. Thése, Université, de Montpeliier, 148pp.

Mattei, X. (1988). The flagellar apparatus of spermatozoa in fish. Ultrastructure and evolution. Biol. Cell 63: 151-158.

Mattei, X. (1991). Spermatozoon ultrastructure and its systematic implications in fishes. Can. J. Zool. 69: 3038-3055.

Nicander, L . , (1970). Comparative studies on the fine structure of vertebrate spermatozoa. In B. Baccetti (ed): Comparative Spermatology. New York Academic Press, 47-55.

Reynolds , E.S . (1963). The use of lead citrate at high $\mathrm{pH}$ as electron opaque stain in electron microscopy. J. Cell Biol. 17: 208-212. 
Siliveira, H . P. Rodrigues, and C. Azevedo (1990). Fine structure of the spermatogenesis of Blennius pholis (Piesces: Blenniidae). J. Submicrosc. Cytol. Pathol. 22: 103-108.

Suquet , M. , G . Dorange; M. H., Omnes., Y. Normant, A. La Roux and C. Fauvel. (1993). Composition of the seminal fluid and ultrastructure of the spermatozoon of turbot (Scophthalmus maximus). J. Fish. Biol. 42: 509516. 


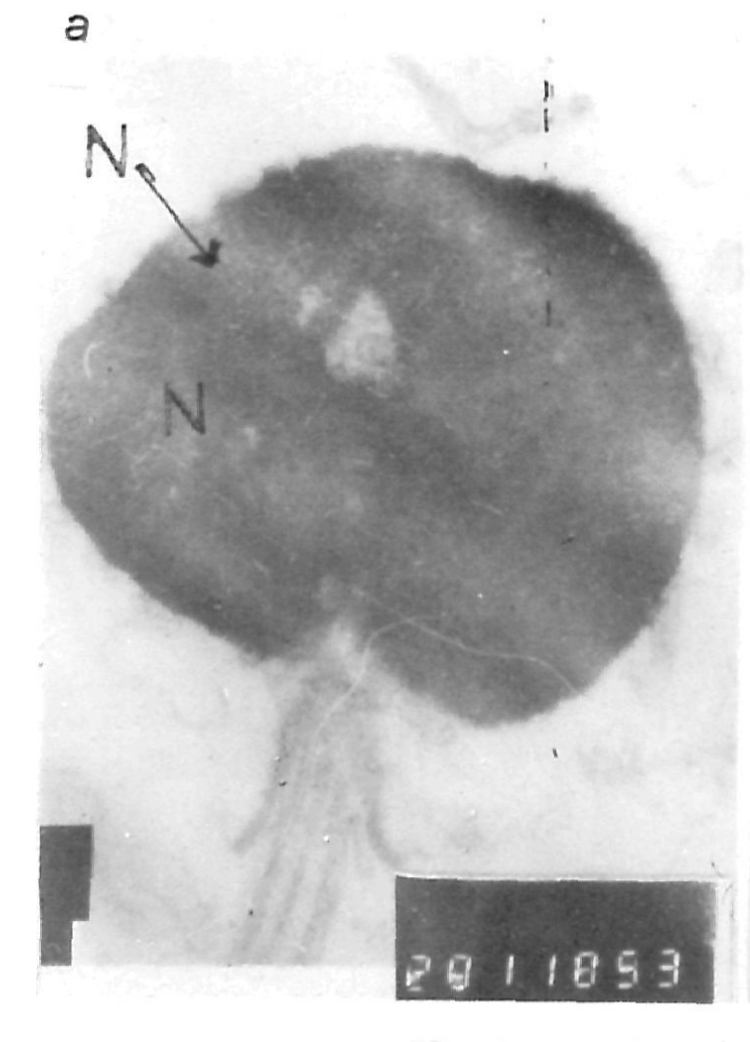

b
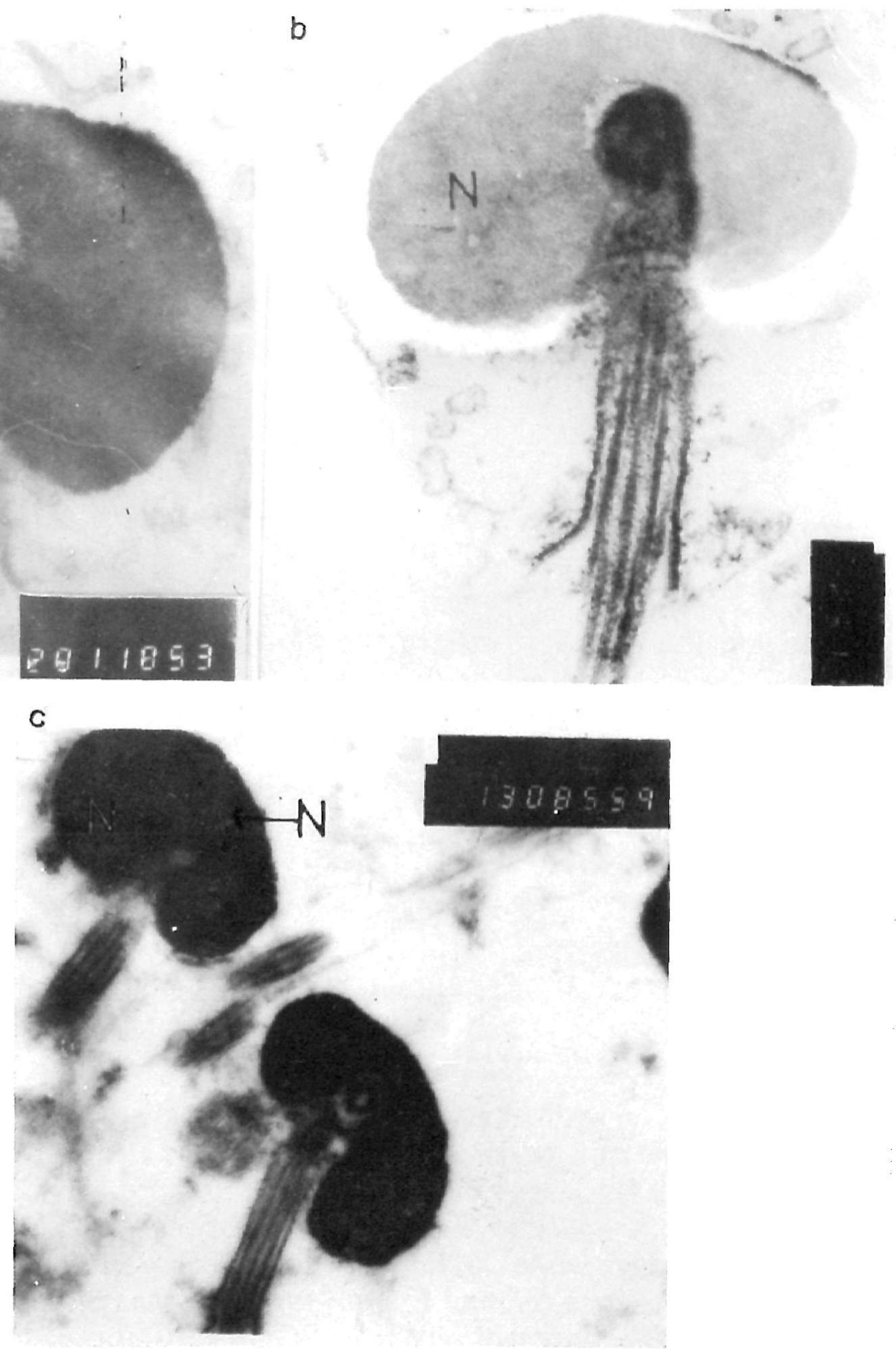

Figure (1): Longitudinl section in spermatozoa of $S$. aurata (a), D. vulgaris (b), and L. mormyrus (c) showing the spherical nucleus $(N)$, and absence of acrosome. 

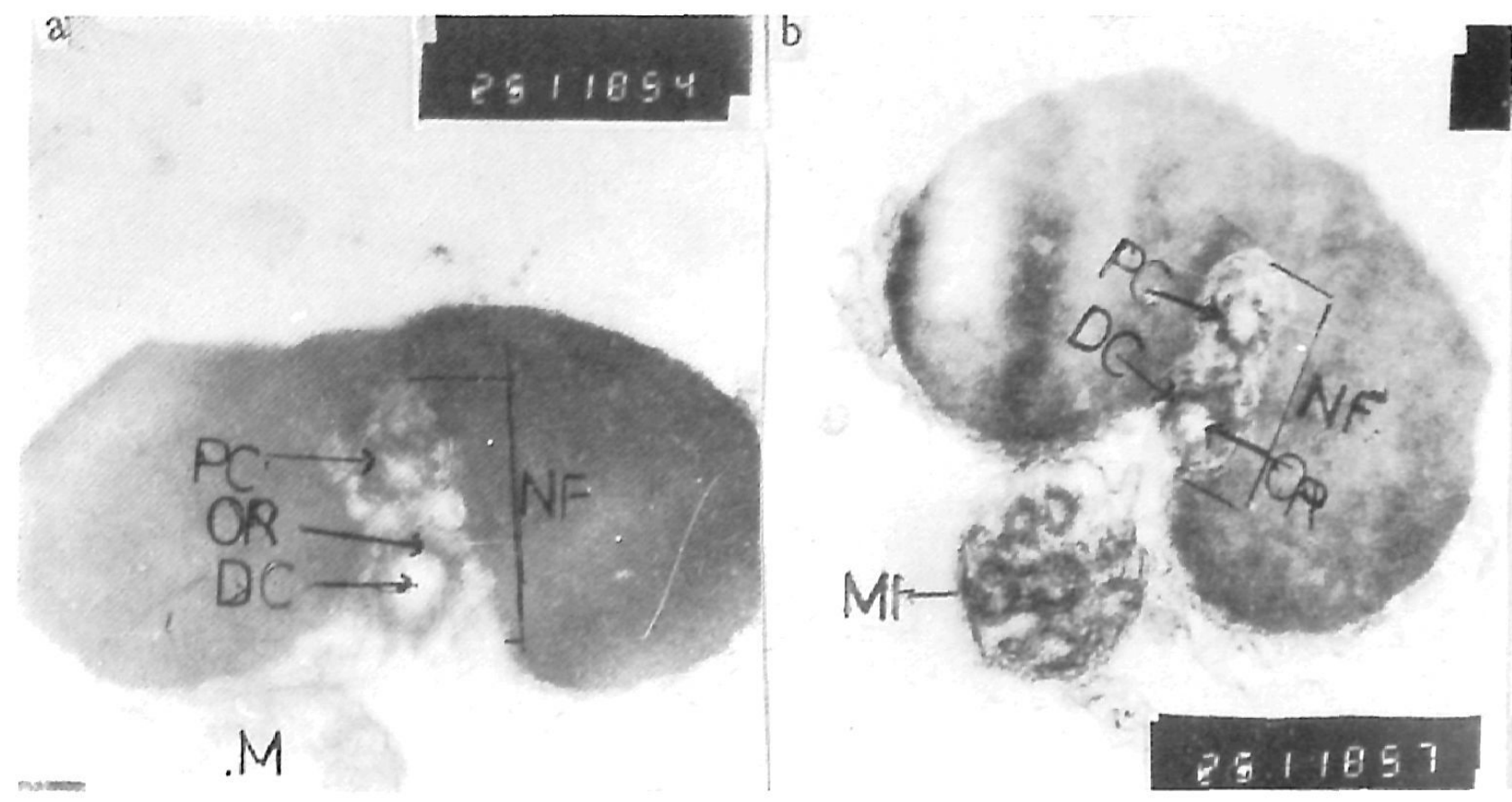

$\mathrm{C}$

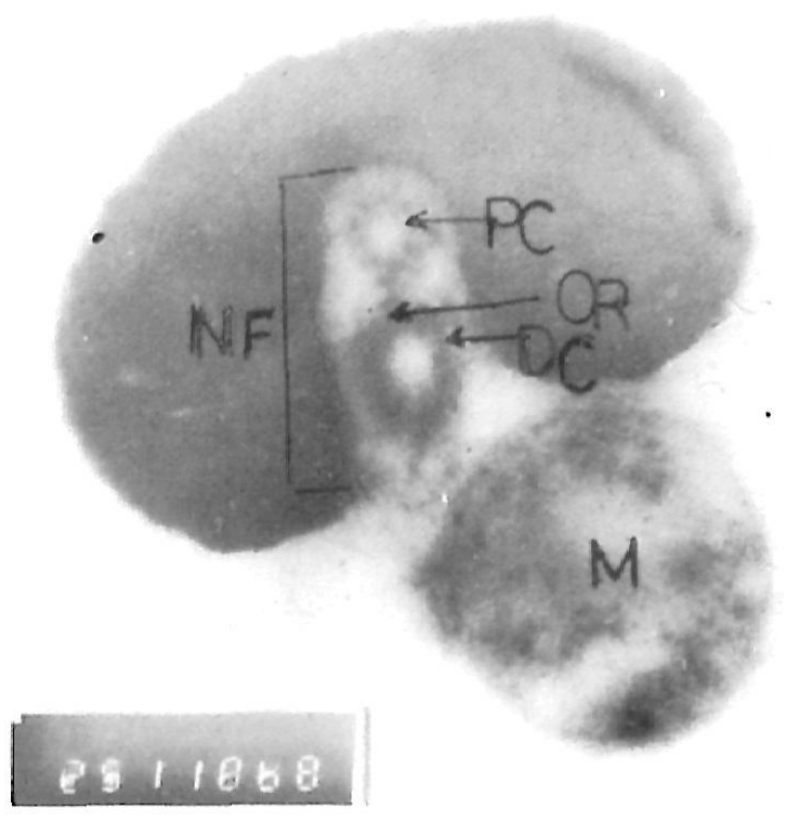

:gure (2) : Longitudinal section of spermatozoa in $S$. aurata (a), D. vulgaris (b), and L. mormyrus (c) showing the nuclear foss $(N F)$, proximal centriole $(P C)$, the distal centriole $(D C)$, the osmiophilic ring $(O R)$, and mitochondria $(M)$. 


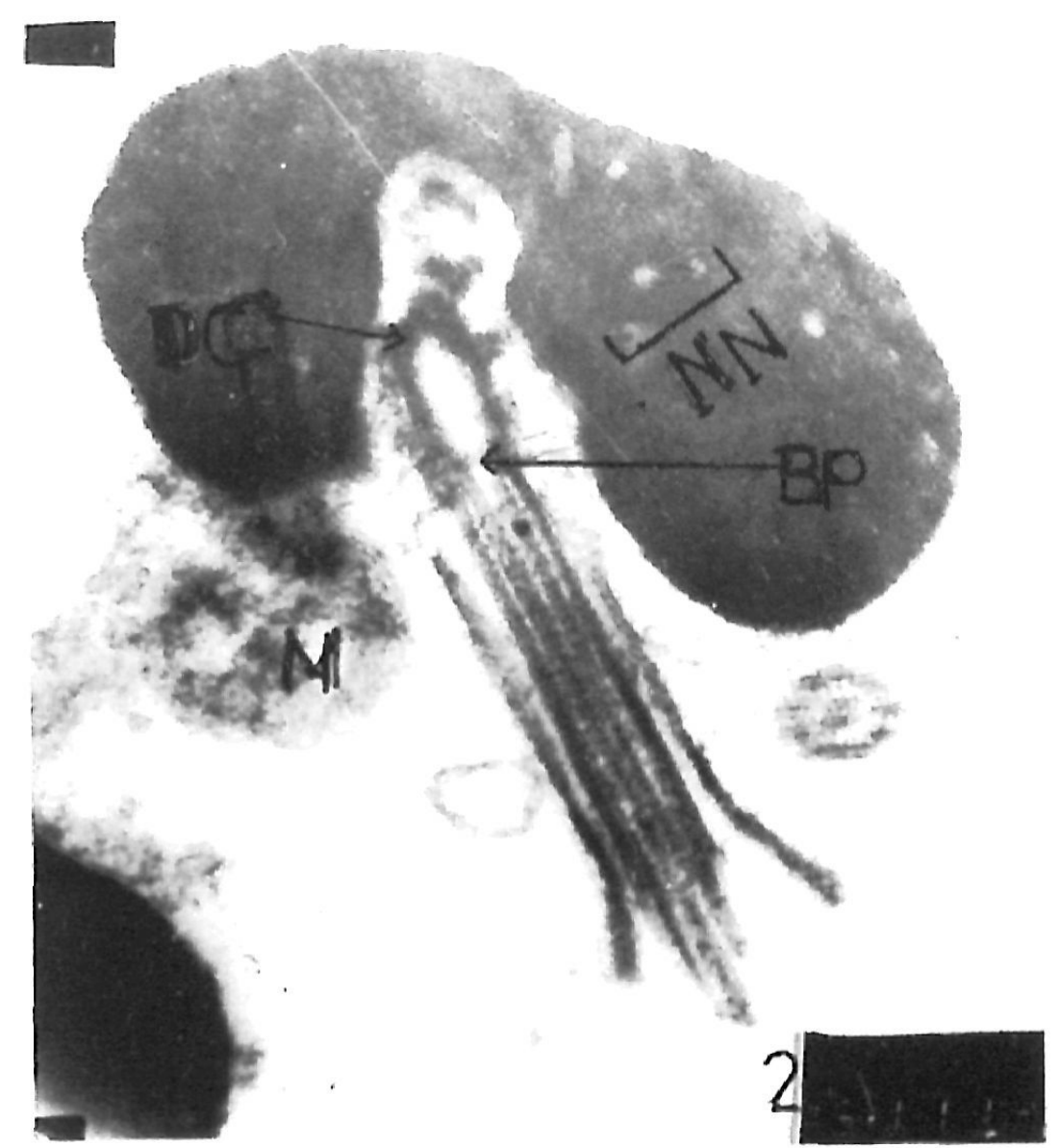

Figure (3) : Sagittal Longitudinal section in spernatozoa of Lithognathus mormyrus showing a bow- tie-shaped nuclear notch (NN), locaated between the basal plate $(B P)$ and the distal centriole (DC). "25,000". 

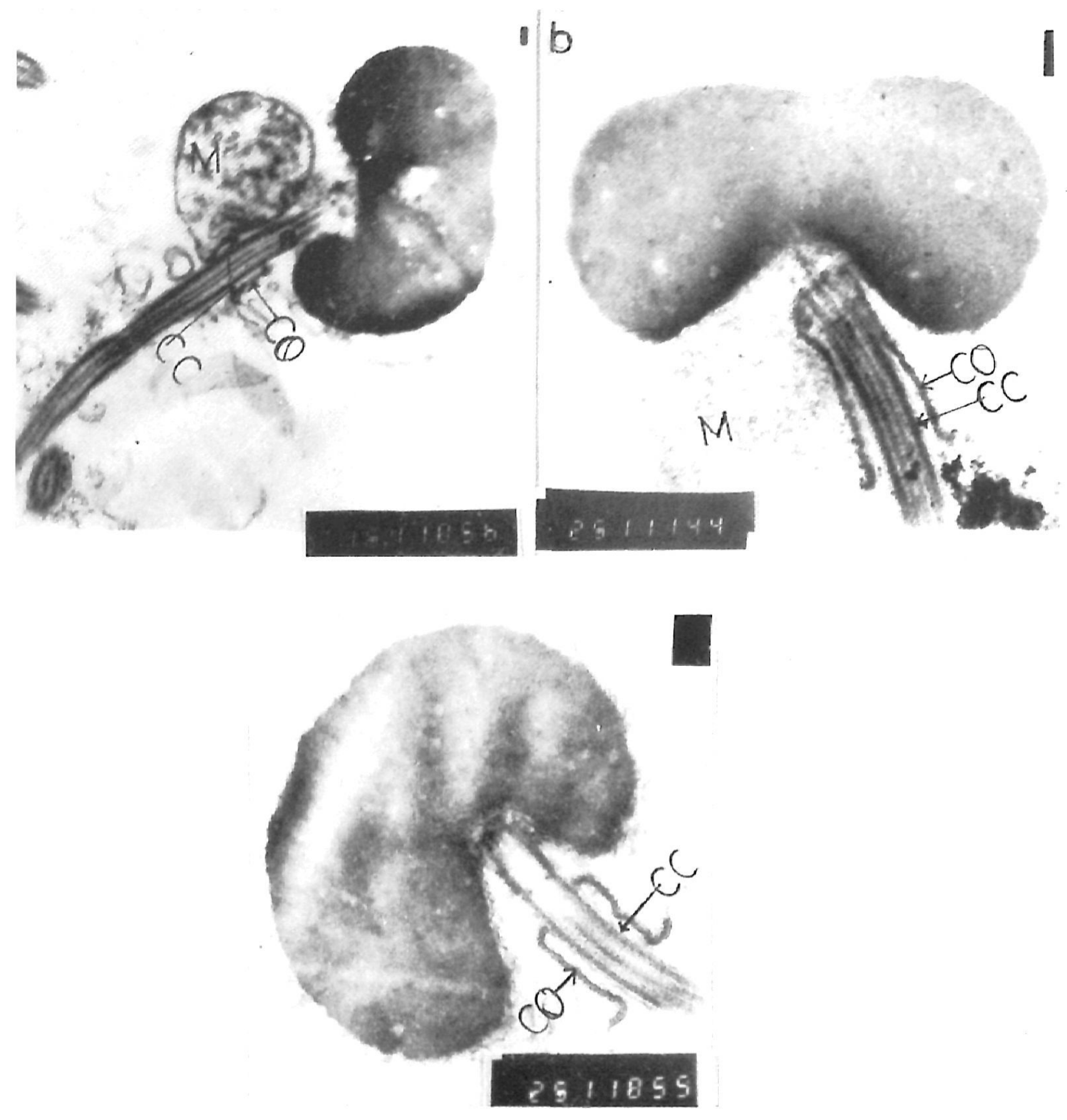

Figure (4) : Longitudinal section in spermatozoa of $S$. aurata (a), D. vulgartis (b), and L. mormyrus (c) showing the mitochondria ring $(M)$, cytoplasmic canal and cytoplasmic collar (C.O). 

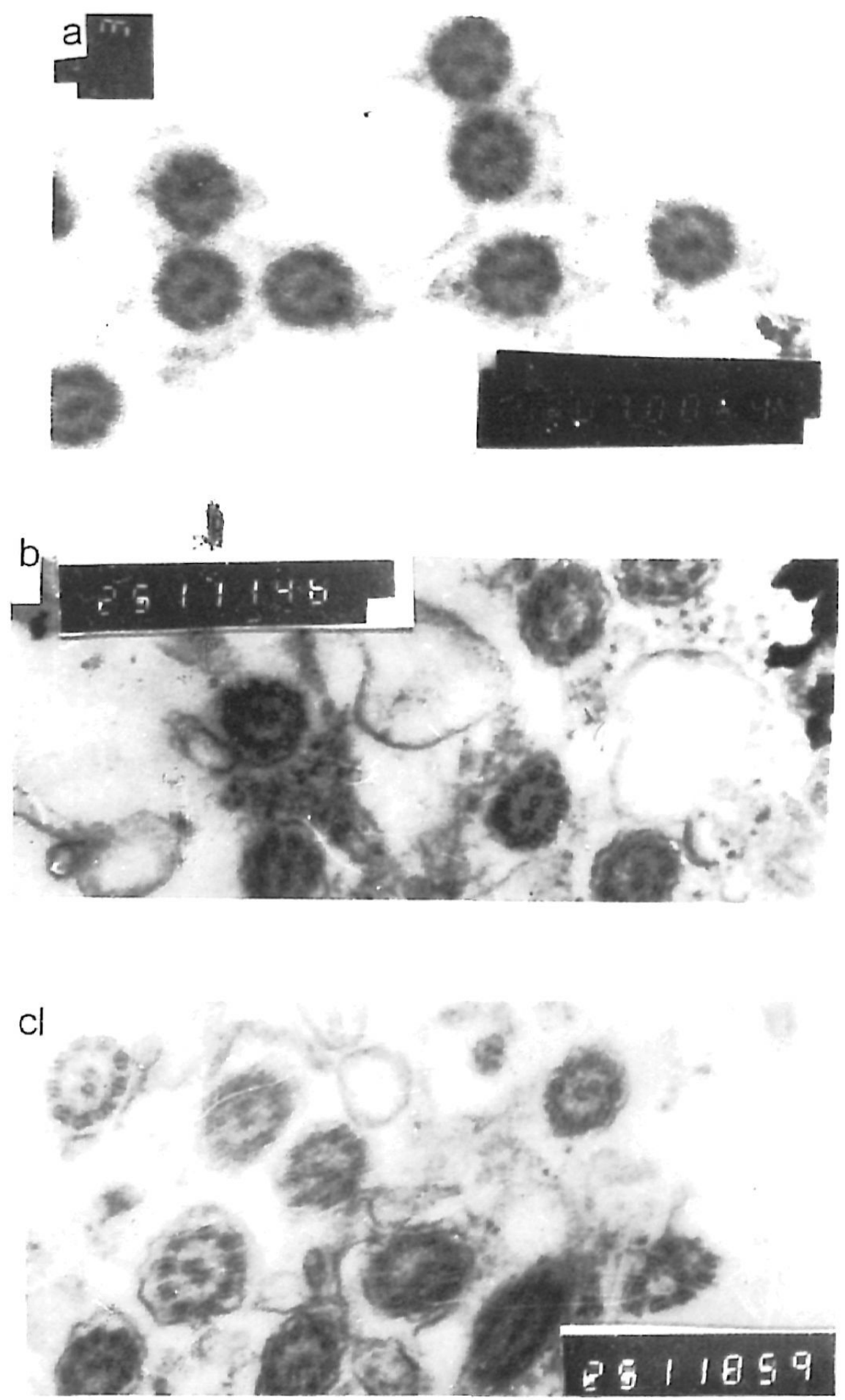

Figure (5): Cross section in axoneme of $S$. aurata (a), D. vulgarts (b), and L. mormyrus (c) showing the $9+2$ axonemal doublet configuration. 


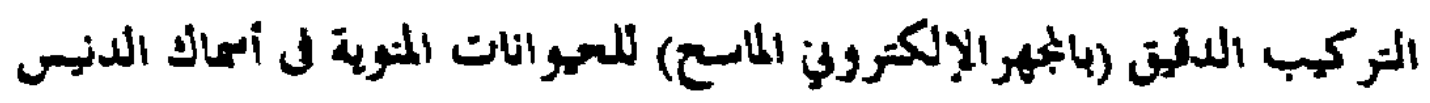

والثشر اغشي والمرعار

(عائلة الأسمهاريلى) من الميال المعرية اللجحر الموسط.

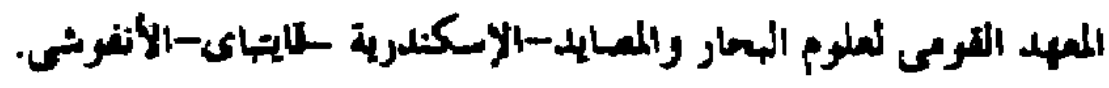

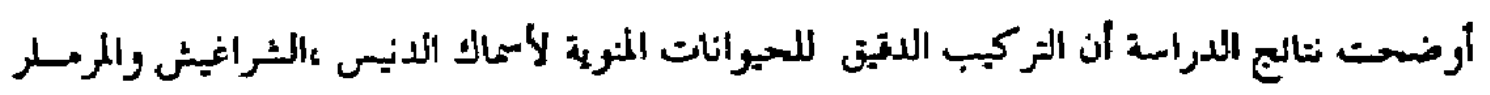

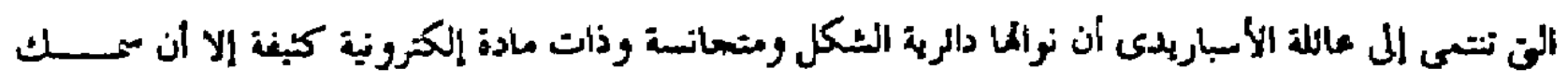

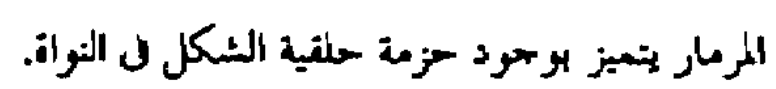

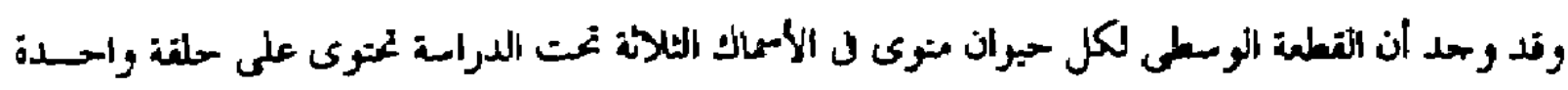

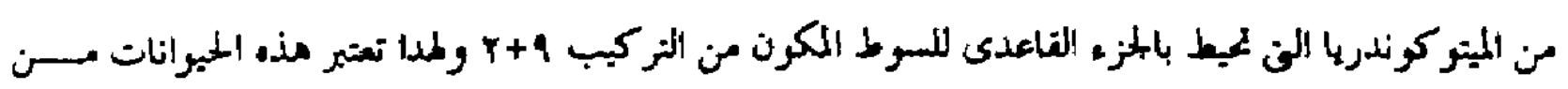

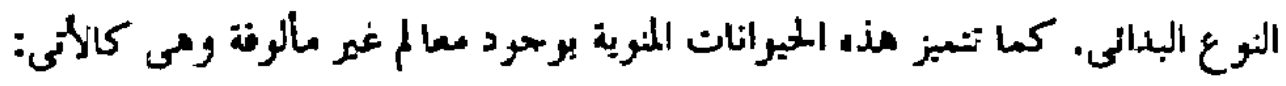

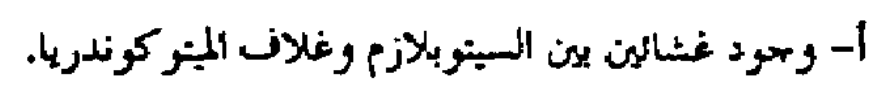

$$
\begin{aligned}
& \text { ب- ومهود تقويف مكورى عميتى له فاعدة التواة. }
\end{aligned}
$$

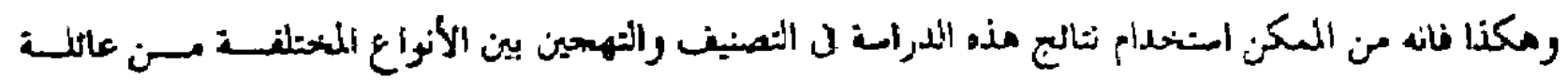

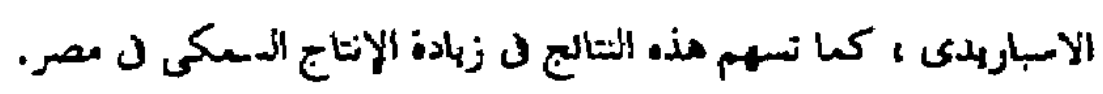

